DOI: 10.17805/trudy.2017.4.3

\title{
ПРЕПОДАВАНИЕ КАК ОБЪЕКТ СТАНДАРТИЗАЦИИ (НА ПРИМЕРЕ МАГИСТРАТУРЫ ПО НАПРАВЛЕНИЮ «ПСИХОЛОГО-ПЕДАГОГИЧЕСКОЕ ОБРАЗОВАНИЕ»)
}

\author{
О. А. Косинова \\ Московский гуманитарный университет
}

\begin{abstract}
Аннотация: В статье представлен первичный сравнительный анализ имеющихся образовательных и профессиональных стандартов на уровне понятийного аппарата и структур. Исследование показывает возможность их сопоставления по содержанию и выработке на этой основе профессионально ориентированных норм подготовки к преподаванию как виду профессиональной деятельности.
\end{abstract}

Ключевые слова: магистратура; вид профессиональной деятельности; педагогическая деятельность; преподавание; профессиональный стандарт; Федеральный государственный образовательный стандарт

\section{TEACHING AS AN OBJECT OF STANDARDIZATION (EXEMPLIFIED BY THE MASTER'S COURSE IN PSYCHO- PEDAGOGICAL EDUCATION)}

\author{
O. A. Kosinova \\ Moscow University for the Humanities
}

\begin{abstract}
The article presents an initial comparative analysis of existing educational and professional standards at the level of the conceptual apparatus and structures. The study shows the possibility of matching their content and elaboration on this basis of the professionally orientated standards of preparation for teaching as a type of professional activity.

Keywords: graduate school; type of professional activity; pedagogical work; teaching; professional standard; Federal state educational standard

\section{ВВЕДЕНИЕ}

На различных уровнях отечественной системы профессионального образования осознана необходимость перехода от образовательных стандартов к профессиональным. В области педагогического (психологопедагогического) образования к настоящему времени имеется несколько регламентирующих документов, различной значимости и содержания, раскрывающих этот вопрос. Проанализируем их.
\end{abstract}




\section{ПРЕПОДАВАНИЕ КАК ОБЪЕКТ СТАНДАРТИЗАЦИИ ФЕДЕРАЛЬНОГО ГОСУДАРСТВЕНЕННОГО ОБРАЗОВАТЕЛЬНОГО СТАНДАРТА}

Согласно Федеральному государственному образовательному стандарту высшего образования по направлению подготовки 44.04.02 Психолого-педагогическое образование (далее - ФГОС) для программ академической магистратуры педагогическая деятельность является одним из видов профессиональной деятельности, на подготовку к которой нацелен названный документ. Ее дополняют научно-исследовательский, научно-методический, организационно-управленческий виды деятельности, сочетающиеся с преподаванием как общее и частное (Федеральный государственный образовательный стандарт ..., 2016: Электр. ресурс).

Термин «преподавание» отсутствует в документе. Однако, названы характеристики профессиональной деятельности психологопедагогического направления, через которые он может быть определен. В соответствии с дидактикой, наиболее близким объектом педагогической деятельности будетвыступать обучение.Реализацияданного процесса раскрывается через следующую систему профессиональных задач: разработка и реализация образовательных программ психолого-педагогического направления; обеспечение условий для учебной деятельности как ведущей для соответствующих возрастных групп (в отношении обучающихся с ограниченными возможностями здоровья употребляется термин «восстановительное обучение»); организация и руководство проектноисследовательской деятельностью обучающихся; организация работы по учебно-методическому обеспечению содержания образования; анализ учебно-воспитательной работы в образовательных организациях, включая инновационные технологии; мониторинг сформированности компетенций обучающихся; разработки их траекторий обучения с учетом индивидуальных и возрастных особенностей; проектирование индивидуальных траекторий обучающихся; консультирование обучающихся, их родителей (законных представителей) и педагогических работников по проблемам обучения; экспертиза образовательных программ.

В. А. Ситаров определяет деятельность педагога (преподавание) как систему действий, направленных на организацию условий для учебнопознавательной деятельности обучаемых и включающих в себя систему соответствующих знаний, умения формировать систему знаний необходимого уровня у учащихся, а также развивать их познавательные интересы и коммуникативные умения (Ситаров, 2004: 7). И. М. Ильинский обращает внимание на способность современных преподавателей высшей школы владеть различными способами организации учебного процесса с опорой на классическую модель обучения (Ильинский, 2016: 9). Таким образом, для определения преподавания как вида профессиональной де- 
ятельности понятие организации является ключевым. ФГОС также оперирует данным термином, но в более широкой трактовке: не только в отношении учебно-воспитательного процесса, но также применительно к общению (межличностным контактам) с обучающимися, их родителями (законными представителями), педагогами; созданию комфортной образовательной среды; учебно-методическому обеспечению образования; защите прав и дополнительному образованию работников. В целом, понятие организации соотносится с другим ключевым термином - сопровождение. Они раскрываются через умения, имеющие значение профессиональных функций: анализа, диагностики, мониторинга, экспертизы, прогнозирования, консультирования.

Существенно важно, что при разработке программы магистратуры образовательная организация вправе дополнять набор компетенций с учетом направленности программы и видов профессиональной деятельности, к которым готовят обучающихся (Федеральный государственный ..., 2016: Электр. ресурс). Закрепление термина компетенции в качестве ключевого понятия образовательных стандартов способствовало разработке компетентностного подхода к осмыслению преподавания в высшей школе (Гневашева, 2013; Фортунатов, 2016: Электр. ресурс).

\section{ПРЕПОДАВАНИЕ КАК ОБЪЕКТ СТАНДАРТИЗАЦИИ ПРОФЕССИОНАЛЬНЫХ СТАНДАРТОВ}

Поскольку преподавание - это вид профессиональной деятельности, то оно может быть осмыслено посредством профессиональных стандартов. В современных условиях данная трактовка представлена исследованиями в ракурсе профессиоцентрического теоретического подхода (Солнышкина, 2016: Электр. ресурс; Шутенко, 2013: 250).

Среди документов Министерства труда и социальной защиты РФ к данному вопросу имеют отношение следующие стандарты: педагог профессионального обучения, профессионального образования и дополнительного профессионального образования; педагог-психолог (психолог в сфере образования).

В профессиональном стандарте педагога профессионального обучения, профессионального образования и дополнительного профессионального образования вид профессиональной деятельности определяется как организация деятельности обучающихся по освоению знаний, формированию и развитию умений и компетенций, позволяющих осуществлять профессиональную деятельность, обеспечение достижения ими нормативно установленных результатов образования; создание педагогических условий для профессионального и личностного развития обучающихся, удовлетворения потребностей в углублении и расширении образования; 
методическое обеспечение реализации образовательных программ (Профессиональный стандарт. Педагог профессионального ..., 2015: Электр. ресурс). Основным видом профессиональной деятельности педагогапсихолога, согласно стандарту, является психолого-педагогическое сопровождение образовательного процесса в образовательных организациях общего, профессионального и дополнительного образования, основных и дополнительных образовательных программ; оказание психолого-педагогической помощи лицам с ограниченными возможностями здоровья, испытывающим трудности в освоении основных общеобразовательных программ, развитии и социальной адаптации, в том числе несовершеннолетним обучающимся, признанным в случаях и в порядке, которые предусмотрены уголовно-процессуальным законодательством, подозреваемыми, обвиняемыми или подсудимыми по уголовному делу либо являющимся потерпевшими или свидетелями преступления (Профессиональный стандарт. Педагог-психолог ..., 2015: Электр. ресурс). Иначе говоря, организация и сопровождение разводятся в профессиональных стандартах в соответствии с назначением профессии:

- для педагога сферы профессионального образования - организация образовательного процесса, то есть, преподавание;

- для педагога-психолога - психолого-педагогическое сопровождение различных категорий обучаемых и воспитуемых.

Причем, оба профессиональных стандарта применимы к образовательным программам магистратуры.

Профессиональный стандарт педагога профессионального обучения, профессионального образования и дополнительного профессионального образования как документ, наиболее полно регламентирующий преподавание на данном этапе стандартизации профессии педагога, содержит структуру ее описания во взаимосвязи следующих понятий: вид профессиональной деятельности, обобщенные трудовые функции, трудовые функции, профессиональные требования. Так, наряду с преподаванием Стандарт называет организацию деятельности, включая учебно-методическое и научно-методическое обеспечение образования. Обобщенная трудовая функция преподавания раскрывается через требования к образованию, опыту практической работы, трудовые действия

\section{ЗАКЛЮЧЕНИЕ}

Таким образом, образовательный и профессиональные стандарты оперируют несколько различными понятийными системами. Применительно к стандартизации преподавания как вида профессиональной деятельности их сходство заключается в его понимании, прежде всего, как деятельности организационной, что соответствует современной научной трактовке данного дидактического понятия. 
Названные стандарты имеют разную структуру. Профессиональные стандарты - более полную и развернутую с точки зрения как понятийного аппарата (вид профессиональной деятельности, обобщенные трудовые функции, трудовые функции, профессиональные требования), так и его наполнения. ФГОС, раскрывающий смысл профессии через связь вида профессиональной деятельности и компетенций, имеет более общий характер и оставляет место для компонента образовательной организации. Вместе с тем, оба стандарта имеют терминологические и содержательные основания для сопоставления и выработки профессионального стандарта преподавателя-выпускника магистратуры.

Осмысление преподавательской деятельности на основе разных стандартов способствует складываю в дидактике высшего образования двух теоретических подходов - компетентностного и профессиоцентрического.

\section{СПИСОК ЛИТЕРАТУРЫ}

Гневашева, В. А. (2013) Особенности современного формирования профессиональных компетенций молодежи через систему высшего профессионального образования // Знание. Понимание. Умение. № 4. С. 5-10.

Ильинский, И. М. (2016) О «правильном образовании» для России XXI века // Знание. Понимание. Умение. № 3. С. 5-31. DOI: 10.17805/ zpu.2016.3.1

Профессиональный стандарт. Педагог профессионального обучения, профессионального образования и дополнительного профессионального образования. Утв. 08.09.2015 г. №608н [Электронный ресурс] // Национальный реестр профессиональных стандартов / Министерство труда и социальной защиты Российской Федерации. URL: http:// profstandart.rosmintrud.ru/obshchiy-informatsionnyy-blok/natsionalnyyreestr-professionalnykh-standartov/reestr-professionalnykh-standartov/ index.php?ELEMENT_ID=48584 (дата обращения: 11.06.2017).

Профессиональный стандарт. Педагог-психолог (психолог в сфере образования). Утв. 24.07.2015 г. №514н [Электронный ресурс] // Национальный реестр профессиональных стандартов / Министерство труда и социальной защиты Российской Федерации. URL: http://profstandart. rosmintrud.ru/obshchiy-informatsionnyy-blok/natsionalnyy- reestrprofessionalnykh-standartov/reestr-professionalnykh-standartov/index. php?ELEMENT_ID=57963 (дата обращения: 11.06.2017)

Ситаров, В.А. (2004) Дидактика : учеб. пособие для студ. высш. пед. учеб. завед. 2-е изд., стереотип. М. : Издательский центр «Академия». 368 с.

Солнышкина, М. Г. (2016) Профессиональный стандарт как основа формирования практико-ориентированных технологий в современном 
социальном образовании (на примере дисциплины «Социальная квалиметрия, оценка качества и стандартизация социальных услуг») [Электронный ресурс] // Научные труды Московского гуманитарного университета. № 6. URL: http://journals.mosgu.ru/trudy/article/view/380 (дата обращения: 25.06.2017). DOI: 10.17805/trudy.2016.6.8

Федеральный государственный образовательный стандарт высшего образования по направлению подготовки 44.04.02 Психологопедагогическое образование (уровень магистратуры) (2016) Утв. 12.05.2016 г. №549 [Электронный ресурс] // Координационный совет учебно-методических объединений и научно-методических советов высшей школы. Портал федеральных государственных образовательных стандартов высшей школы. URL: http://fgosvo.ru/news/5/1868 (дата обращения: 11.06.2017).

Фортунатов, А.А. (2016) О методологической культуре обучающихся в магистратуре [Электронный ресурс] // Научные труды Московского гуманитарного университета. №6. URL: http://journals.mosgu.ru/trudy/article/ view/374 (дата обращения: 25.06.2017). DOI: 10.17805/trudy.2016.6.2

Шутенко, А. И. (2013) Социокультурные измерения устойчивого педагогического процесса в высшей школе // Знание. Понимание. Умение. №4. C. 249-251.

Дата поступления: 12.07.2017 г.

Косинова Оксана Анатольевна - доктор педагогических наук, доцент, профессор кафедры педагогики и психологии высшей школы Московского гуманитарного университета. Адрес: 111395 , Россия, г. Москва, ул. Юности, д. 5. Тел.: +7 (499) 374-78-82. Эл. адрес: ido@mosgu.ru

Kosinova Oksana Anatolievna, Doctor of Pedagogy, Associate Professor, Professor, Department of Pedagogy and Psychology of Higher School, Moscow University for the Humanities. Postal address: 5, Yunosti St., Moscow, Russian Federation 111395. Tel.:+7 (499) 374-78-82.E-mail: ido@mosgu.ru

\section{Для циитирования:}

Косинова О. А. Преподавание как объект стандартизации (на примере магистратуры по направлению «Психолого-педагогическое образование») [Электронный ресурс] // Научные труды Московского гуманитарного университета. 2017, № 4. URL: http://journals.mosgu.ru/trudy/article/view/526 (дата обращения: дд.мм.гг.). DOI: 10.17805/trudy.2017.4.3 